\title{
A nulidade absoluta pela não intervenção do representante do Ministério Público em atos essenciais da ação penal pública
}

\author{
The absolute nullity by the non intervention of the public \\ prosecution in essential acts of the public penal action
}

\section{Francisco Ortêncio de Carvalho ${ }^{1}$}

Ministério Público do Estado de Pernambuco - Recife/PE ortenciocarvalho@gmail.com

lattes.cnpq.br/1942703566599103

orcid.org/0000-0001-5479-5142

\begin{abstract}
Resumo: A realização de atos essenciais no processo penal, precipuamente de audiências de instrução criminal, sem a participação do Ministério Público, viola o sistema acusatório. Tal constatação demanda da intelligentsia uma revisitação do tema [espécies dos atos jurídicos processuais penais (estruturais e acessórios) e seus efeitos], para corrigir o problema da inobservância do paradigma do sistema acusatório, que tem provocado precedentes jurisprudenciais controversos e caóticos, sendo nítido o paradoxo entre a ciência e a práxis jurídica. O propósito é reexaminar o tema a partir do cross-examination, sendo primordial a percepção e a classificação adequadas das espécies dos atos jurídicos processuais, com uso de premissa que distinga ato essencial, de ato acessório, e seus efeitos. Este trabalho neutraliza a controvérsia da ausência do Ministério Público em audiência ser ato nulo ou anulável, aprimorando o estado da arte com o reconhecimento de que a inquirição direta das testemunhas é ato essencial e sua ausência acarreta nulidade absoluta. Os atos essenciais não podem ser realizados sem seu autor e tratá-los como se fossem secundários
\end{abstract}

1 Doutor em Ciências Jurídicas e Sociais - UMSA, com pós-doutorado em Direito pela Università degli Studi di Messina/Itália. Membro do Conselho Editorial da Núria Fabris Editora (Porto Alegre/RS). Membro do Ministério Público do Estado de Pernambuco (promotor de Justiça). 
provoca error in procedendo. O pas de nullité sans grief somente se aplica aos atos acessórios. O modelo epistemológico proposto funciona como premissa fundamental de interpretação do tema, contribuindo com o avanço da grande área.

Palavras-Chave: processo penal; ausência do Ministério Público; cross-examination; ausência de ato essencial; nulidade absoluta.

AвstRACT: The practice of essential acts on criminal proceedings, especially criminal investigation hearings, without the participation of public prosecution, violates the adversarial system. This finding demands a revision of the theme [species of criminal procedural acts (structural and accessories) and their effects], by the intelligentsia, to correct the problem of non-compliance with the paradigm of adversarial system which has caused controversial and chaotic legal precedents and it is clear the paradox between science and legal praxis. The proposal is to re-examine the theme, by the cross-examination paradigm, poiting out that it is out of the utmost importance a proper perception and classification of the legal acts species, using a premise in which one can distinguish what is an essential from what is an accessory act, and its effects. This study neutralize the controversy over criminal investigation hearings without the participation of public prosecution being a void or voidable act, improving the state of the art with the acknowledgement of the direct inquiry of witnesses is an essential act and its absence entails absolute nullity. The essential acts cannot be carried out without their plaintiff and treating it as if it were secondary is an error in procedendo. The pas de nullité sans grief only applies to accessories acts. The epistemological model proposed works as a fundamental premise of interpretation of the theme, contributing to the advancement of the big area.

KEYWORDS: criminal proceedings; absence of public prosecutor; crossexamination; absence of an essential act; absolute nullity.

SUMÁRIO: Introdução; 1. Da antiga configuração normativa: premissa superada; 2. Da atual configuração normativa: premissa vigente; 3. Os sistemas processuais penais: inquisitório e acusatório; 3.1. Gestão da prova no sistema acusatório; 4. Da violação do devido processo legal; 5. Das nulidades no direito processual penal; 5.1. Ato processual penal e nulidades: breves considerações; 5.2. Reflexos das distorções na jurisprudência; 6. Proposta de premissa de balizamento para interpretação do tema; Considerações Finais; Referências. 


\section{INTRODUÇÃO}

Práxis recente vem chamando a atenção de parte do mundo jurídico, precipuamente na seara processual penal: a realização de audiências e a prática de outros atos essenciais sem a participação do representante do Ministério Público. Houve o registro no Brasil, inclusive, de uma recomendação nesse sentido confirmada pelo Conselho Nacional de Justiça - CNJ (PCA n ${ }^{\circ}$ 0000071-07.2015.2.00.0000). ${ }^{2}$ Trata-se da Recomendação $\mathrm{n}^{\circ}$ 01, de 13 nov. 2014, do Conselho Superior da Magistratura do Egrégio Tribunal de Justiça de Pernambuco, ${ }^{3}$ que autoriza juízes de primeiro grau a realizarem audiências estando ausente o promotor de Justiça, titular da ação penal pública. A história registra que noutros tempos (antes da CF/1988) havia, excepcionalmente, a nomeação de promotor ad hoc, mas nunca a realização do ato estando ausente o Ministério Público, sendo este essencial, e não apenas eventual, ${ }^{4}$ à administração da Justiça no modelo constitucional vigente. $\mathrm{O}$ retrocesso, pois, é manifesto.

O tema tem causado muita celeuma, sobretudo em face de decisões em diversos sentidos: ora entendendo que se trata de nulidade absoluta; ${ }^{5}$

2 BRASIL. Conselho Nacional de Justiça. PCA n ${ }^{0}$ 0000071-07.2015.2.00.0000. Disponível em: <http://www.cnj.jus.br/InfojurisI2/Jurisprudencia.seam?jurisprudenciaIdJuris $=48307 \&$ indiceListaJurisprudencia $=0 \&$ tipoPesquisa $=$ LUCENE\&firstResult=0>. Acesso em: 01 ago. 2017.

3 BRASIL. Tribunal de Justiça de Pernambuco. Recomendação no 01/2014. Disponível em: <https://www.jusbrasil.com.br/diarios/74366033/djpe-1707-2014-pg-380>. Acesso em: 02 ago. 2017.

Recomendação $\mathrm{n}^{\mathrm{o}}$ 01/2014, de 10 de julho de 2014 (Protocolo $\mathrm{n}^{\mathrm{o}}$ 77866/2014), do Exm ${ }^{\circ}$ Sr. Des. Frederico Ricardo de Almeida Neves, Presidente do Conselho da Magistratura de Pernambuco: "Recomenda aos Juízes do primeiro grau que, mesmo na ausência do representante do Ministério Público, sejam realizadas as audiências de instrução e julgamento designadas, desde que o parquet tenha sido regularmente intimado para o ato processual respectivo".

4 LIMA, Charles Hamilton Santos; CARNEIRO, André Silvani da Silva. A função do Ministério Público é essencial, não apenas eventual. Disponível em: <http:// www.conjur.com.br/2017-jul-17/mp-debate-funcao-ministerio-publico-essencial-nao-apenas-eventual>. Acesso em: 01 ago. 2017.

5 BRASIL. Tribunal de Justiça do Rio Grande do Sul. Apelação Crime No 70054048624. Terceira Câmara Criminal. TJRS. Relator: Jayme Weingartner Neto. Julgado em 13/03/2014. Diário da Justiça do dia 17/06/2014. 
ora que se caracteriza nulidade relativa, ${ }^{6}$ aplicando-se a regra pas de nullité sans grief - segundo a qual nenhum ato será declarado nulo, se da nulidade não resultar prejuízo para a acusação ou para a defesa - o que induz à perfunctória percepção de ser o tema complexo. Entretanto, observando que o cerne da questão é inerente ao novo paradigma estabelecido pela Lei $n^{\circ}$ 11.690/08, que modificou a sistemática processual penal alterando o modelo presidencialista de condução de audiências pelo magistrado, percebe-se que a questão não é complexa para se responder à pergunta: tal espécie de nulidade é absoluta ou relativa? Nesse sentido destaca Pacelli que:

[...] enquanto a nulidade relativa diz respeito ao interesse das partes em determinado e específico processo, os vícios processuais que resultam em nulidade absoluta referem-se ao processo penal enquanto função jurisdicional, afetando não só o interesse de algum litigante, mas de todo e qualquer (presente, passado e futuro) acusado, em todo e qualquer processo. O que se põe em risco com a violação das formas em tais situações é a própria função judicante, com reflexos irreparáveis na qualidade da jurisdição prestada. ${ }^{7}$

Embora esse fato produza impacto direto na qualidade da prestação jurisdicional penal, que deve ser resultado de um processo que obedeça às normas cogentes, os tribunais brasileiros, sobretudo o Superior Tribunal de Justiça (STJ), não têm tratado o assunto com a profundidade que ele merece, embasando seus posicionamentos no antigo paradigma que regia a matéria: sistema presidencialista de condução de audiências. Uma revisitação do tema, sob a ótica do paradigma do cross-examination, se faz necessária para uma adequada percepção das espécies dos atos processuais penais praticados em audiência, com a busca das premissas apropriadas a um silogismo coerente. Eis o propósito deste artigo.

Para uma percuciente análise dos fatos, com percepção otimizada, se faz necessária a delimitação das premissas capazes de sustentar uma conclusão coerente. A atividade hermenêutica se desenvolve a partir da

6 BRASIL. Superior Tribunal de Justiça - STJ. RHC 14378 / PR Recurso Ordinário em Habeas Corpus 2003/0060121-3. Relator: Ministro Felix Fischer. T5 - Quinta Turma. Julgado em 18/05/2004. DJ 07/06/2004 p. 239.

7 PACELLI, Eugênio. Curso de processo penal. 21. ed. rev., atual. e ampl. São Paulo: Atlas, 2017. p. 390. 
construção de raciocínio lógico-dedutivo e a validade da conclusão a que se chega, diante de uma situação concreta, depende diretamente do cotejo apropriado entre as premissas estabelecidas, ou seja, a interpretação das premissas deve ser adequada, sob pena de invalidar a conclusão do conhecimento produzido. E é justamente na fixação das premissas necessárias para raciocinar a presente situação que se verifica a necessidade de se levantar alguns tópicos fundamentais para o desenvolvimento de um raciocínio elaborado, apresentado sob a forma de argumentos, onde as conclusões devem ser sustentadas por premissas coerentes e plausíveis. Para isso é imprescindível a compreensão do paradigma que rege a matéria processual penal no Brasil, neste momento histórico.

\section{DA ANTIGA CONFIGURAÇÃO NORMATIVA: PREMISSA SUPERADA}

Um olhar atento sobre o paradigma estabelecido pela Lei n. 11.690/08, que alterou dispositivos relativos à prova, conduz à percepção de que houve mudança do cenário jurídico que rege a matéria, precipuamente no que tange ao modelo presidencialista, no qual o juiz conduzia a audiência e fazia diretamente perguntas às testemunhas, cabendo às partes, em caráter suplementar, fazer reperguntas após o juiz, complementando a inquirição. O juiz, pois, era o primeiro a colher prova em audiência, suplementado pelas partes. Como registra Nucci, portanto, "a Lei 11.690/2008 eliminou o sistema presidencialista de inquirição das testemunhas [...]". ${ }^{8}$

Registra a história dos precedentes acerca das nulidades que a quinta turma do Superior Tribunal de Justiça, no julgamento do HC 19.085/ GO, ainda no ano de 2003, entendia que nesse modelo presidencialista a ausência do MP causava, quando muito, nulidade relativa, condicionada à demonstração do prejuízo, se aplicando a regra insculpida no art. 564, III, “d”, do CPP, prevalecendo o princípio pas de nullité sans grief. Entretanto, Tourinho Filho entendia que mesmo na sistemática anterior à mudança de paradigma ocorrida em 2008, tal espécie de nulidade seria absoluta:

8 NUCCI, Guilherme de Souza. Código de Processo Penal comentado. 15. ed. rev., atual. e ampl. - Rio de Janeiro: Forense, 2016. p. 430. 
Observa-se que o art. 572 está assim redigido: As nulidades previstas no art. 564, $n^{o} I I I$, letras $d$ e e, segunda parte, $g$ e $h$, e $n^{o} I V$, considerar-se-ão sanadas... Sem dúvida a expressão segunda parte, contida no texto, refere-se tanto à letra $d$ como à letra $e$. Não fosse assim, o texto diria: ... no art. 564, $n^{\circ}$ III, letra d, e, segunda parte, g e $h .$. Disse entretanto: letras d e e, segunda parte. O que nos leva a tal resultado semântico é a própria gramática do texto; o legislador faz seguir um adjunto adverbial de localização, no art. 564, adjunto marcado pela preposição em, uma série de apostos, como as expressões $n^{\circ} I I I$, letras $d$ e e segunda parte, $g$ e $h, n^{o} I V$. O aposto é uma sequência que diz respeito ao um ser, explicitando-o. O primeiro ser explicitado, na espécie, é o adjunto adverbial no art. 564, que sofre uma explicitação restritiva $n^{o} I I I$. Este, por sua vez, é explicitado restritivamente pelas aposições letras $d$ e $e, g$ e $h$, e $n^{o} I V$. Assim, também, as oposições letras $d$ e $e$ vêm explicitadas por uma oposição segunda parte, restritiva delas. Logo, o oposto segunda parte refere a ambas as letras. Então o não-comparecimento do ministério público em qualquer termo da ação por ele intentada implica nulidade insanável. Mas, se se tratar de ação penal pública intentada mercê de queixa (art. 29), a nulidade é sanável, nos termos do art. 572 do CPP. (sic) ${ }^{9}$

Porém, independentemente das posições divergentes à época, acerca da matéria, esse modelo descrito pela velha redação do art. 212, do $\mathrm{CPP}^{10}$ não existe mais, de modo que insistir em utilizar essa premissa, um paradigma inerente ao antigo modelo presidencialista anterior à Lei $\mathrm{n}^{\mathrm{o}}$ 11.690/08, é um equívoco. Logo, os precedentes que se baseiam no antigo modelo não podem servir de base a uma conclusão cientificamente válida.

\section{Da atual configuração normativa: PREMissa Vigente}

Com o advento da lei $n^{0} 11.690 / 08$, os papéis desempenhados pelos protagonistas da atuação processual penal mudaram. Agora é o

9 TOURINHO FILHO, Fernando da Costa. Código de processo penal comentado. São Paulo: Saraiva, 1997. v. 2. p. 209.

10 Antiga redação do Art. 212, do CPP: “As perguntas das partes serão requeridas ao juiz, que as formulará à testemunha. O juiz não poderá recusar as perguntas da parte, salvo se não tiverem relação com o processo ou importarem repetição de outra já respondida”. Destaques nossos. 
magistrado quem faz as perguntas complementares àquelas formuladas pelas partes, conforme estabelece o parágrafo único, do art. 212, do CPP: "Sobre os pontos não esclarecidos, o juiz poderá complementar a inquirição." É nítido que os papéis e os momentos da atuação do Ministério Público, da Defesa e do Juiz, em audiência, modificaram-se. ${ }^{11}$ $\mathrm{O}$ atual paradigma é caracterizado pelo sistema de inquirição direta das testemunhas. A reforma, afastando-se do sistema presidencialista, adotou o sistema de inquirição direta ou do cross-examination que, nos Estados Unidos, se baseia no adversary system, em que o juiz se situa em posição secundária na produção das provas. ${ }^{12}$ Nesse sentido Arantes Filho conclui que:

A alteração do Código de Processo Penal, operada pela Lei n ${ }^{\circ}$ 11.690, de 2008, evidencia a introdução de alguns dos aspectos do "cross-examination" no direito processual penal brasileiro: a formulação direta de perguntas pelas partes e a subsidiariedade da feitura de perguntas pela autoridade judicial (art. 212, caput e parágrafo único)". ${ }^{13}$

Não é preciso gastar rios de tinta para ensejar a compreensão de que no atual modelo normativo a atuação do representante do Ministério Público em audiência, precipuamente quando da oitiva das testemunhas por ele arroladas, é imprescindível, indispensável à produção de provas, eis que o ato de fazer perguntas diretas às testemunhas, pelo autor da ação, é essencial, uma vez que o juiz fará as perguntas complementares. Por dedução lógica, a falta de ato essencial causa nulidade, e esta é absoluta, pois o prejuízo é presumido, conforme o sistema de nulidades. Logo, a

11 Atual redação do artigo 212, do CPP: “As perguntas serão formuladas pelas partes diretamente à testemunha, não admitindo o juiz aquelas que puderem induzir a resposta, não tiverem relação com a causa ou importarem na repetição de outra já respondida”. (Redação dada pela Lei no 11.690, de 2008). Destaques nossos.

12 MENDONÇA, Andrey Borges de. Nova reforma do código de processo penal: comentada artigo por artigo. São Paulo: Método, 2008. p. 194.

13 ARANTES FILHO, Marcio Geraldo Britto. O “cross-examination" como procedimento probatório para produção de prova testemunhal no direito processual penal brasileiro. 2016. Tese (Doutorado em Direito) - Faculdade de Direito, Universidade de São Paulo, São Paulo. p. 223-224. 
produção da prova testemunhal "deve ocorrer com a presença das partes, em contraditório, perante a autoridade judicial". ${ }^{14}$

A estrutura do atual modelo de realização de audiências criminais é composta pelos seguintes atos: a) $1^{\circ}$ ato - perguntas diretas pelo autor da ação para ouvida das testemunhas arroladas na exordial acusatória; $2^{\circ}$ ato - perguntas diretas pela defesa; $3^{\circ}$ ato - perguntas complementares pelo juiz, ou b) $1^{\circ}$ ato - perguntas diretas pela defesa para oitiva das testemunhas por ela arroladas; $2^{\circ}$ ato - perguntas diretas pelo Ministério Público; $3^{\circ}$ ato - perguntas complementares pelo juiz. Tanto as perguntas diretas do autor da ação, quanto da defesa, na inquirição de suas testemunhas, são atos estruturais, essenciais no atual modelo. Não são, pois, meros atos acessórios, dispensáveis. Para Mossin:

Não resta a menor dúvida de que há atos processuais essenciais e atos processuais acidentais no âmbito da sistemática processual penal. Os atos processuais essenciais são imprescindíveis, insubstituíveis para a formação e o desenvolvimento regular da instância [...]. A ausência ou inexistência desses atos estruturais implica a nulidade absoluta do processo, independentemente do eventual prejuízo às partes, já que este se presume..$^{15}$

Embora o modelo vigente esteja posto, de maneira clara, pelo ordenamento jurídico, consistindo no sistema do cross-examination, o Conselho Nacional de Justiça brasileiro confirmou recomendação em sentido contrário, possibilitando que juízes realizem audiência criminal sem que esteja presente o representante do Ministério Público, sob o fundamento de ser ato acessório, desconsiderando totalmente o paradigma que rege a matéria.

Ademais, é importante consignar a partir da lição de Gloeckner, que "a forma processual penal não é simplesmente uma mera ritualística.

14 ARANTES FILHO, Marcio Geraldo Britto. O "cross-examination" como procedimento probatório para produção de prova testemunhal no direito processual penal brasileiro. 2016. Tese (Doutorado em Direito) - Faculdade de Direito, Universidade de São Paulo, São Paulo. p. 123.

15 MOSSIN, Heráclito Antônio. Nulidades no direito processual penal. São Paulo: Atlas, 1998. p. 44. 
Nela cristalizam-se os direitos fundamentais cuja inaplicabilidade fere a própria legitimação da pena". ${ }^{16}$

\section{OS SISTEMAS PROCESSUAIS PENAIS: INQUISITÓRIO E ACUSATÓRIO}

No paradigma anterior a 2008 se percebiam resquícios do inquisitorialismo brasileiro como ponto nevrálgico ainda persistente nos tempos atuais, no qual se baseia o CNJ de maneira equivocada. Embora a doutrina esposasse que o inquérito policial tenha caráter eminentemente "inquisitivo" e o processo penal, em sentido estrito, tenha caráter acusatório, cuja junção dos dois sistemas - da fase policial e da fase processual - tenha sido chamado de sistema misto que, nas palavras de Giacomolli era "um 'ambíguo garantismo inquisitório', um 'corpo com duas cabeças', sem alteração das estruturas", ${ }^{17} \mathrm{o}$ inquisitorialismo brasileiro mantinha-se presente na legislação quanto à definição de modelo inerente também à fase processual, sem que houvesse um contraditório puro. Aliás Amaral, com um olhar histórico, afirma que "não estamos imersos em nenhuma análise a partir de ditos sistemas processuais penais puros - todos são em maior ou menor medida mesclados". ${ }^{18}$ Acontece que a Constituição de 1988 é clara ao adotar o sistema acusatório, sem a possibilidade de resquícios de viés inquisitorial.

Em decorrência disso, mesmo após a CF/1988, o modelo infraconstitucional mantinha resquícios de atos inquisitórios dentro do processo penal em sentido estrito, a exemplo das partes que - à exceção do rito procedimental do júri que é de inspiração inglesa - não tinham direito sequer de indagar diretamente as testemunhas e deveriam fazê-lo através do filtro do magistrado que, analisando a pertinência das perguntas sugeridas, delas se apropriava, reformulando-as para, em seguida, ditar as respostas da testemunha - prevalência da forma escrita sobre a oral -, o que fazia da maneira que melhor lhe conviesse, por vezes deturpando - sem que

16 GLOECKNER, Ricardo Jacobsen. Nulidades no processo penal. 3. ed. São Paulo: Saraiva, 2017. p. 340.

17 GIACOMOLLI, Nereu José. Reformas (?) do processo penal: considerações críticas. Rio de Janeiro: Editora Lúmen Juris, 2008. p. 7.

18 AMARAL, Augusto Jobim do. Nas entranhas do processo penal: para uma viragem democrática. Revista da Faculdade de Direito da UERJ, v. 2, n. 26, 2014. p. 27. 
isso seja necessariamente entendido como intencional ou consciente -, na síntese externada ao ditar ao escrivão, o que foi descrito pela testemunha.

Num sistema integralmente acusatório isso não é admitido, sob pena de se caracterizar um inquisitorialismo disfarçado. Apesar da Lei 11.690/08 ser clara, "o sistema brasileiro acaba conformando na realidade concreta um sistema inquisitório, através da deformação a que são submetidas na prática as previsões legais". ${ }^{19}$ Assim, insistir o CNJ, diante do modelo posto, que a inquirição das testemunhas do rol da denúncia possa ser feita somente pelo juiz é repristinar tais resquícios que foram abolidos, em conformidade com o mandamento constitucional, pela reforma de 2008 que definiu que a inquirição direta das testemunhas cabe às partes. Logo, os precedentes do STJ e o posicionamento do CNJ acerca do tema aqui tratado, da forma como estão, deixa "claro que o sistema permanece preso às amarras do inquisitorialismo". ${ }^{20}$

\subsection{Gestão da PROVA NO SISTEMA ACUSATÓRIO}

No sistema acusatório há papéis bem definidos para todos os envolvidos e, visando também à preservação dos princípios da imparcialidade e da inércia do juiz é que a inquirição direta das testemunhas em audiência, na reforma de 2008, passou para as partes, sobretudo para o Ministério Público que tem a incumbência de provar o por ele alegado.

Afora os fundamentos da essencialidade do ato, o comprometimento da imparcialidade do julgador - ser humano que é - também é causa de prejuízo presumido, pois a ausência de neutralidade quando aliada à postura ativa na colheita da prova revela a prejudicialidade do modelo, inserida na concreta probabilidade de quebra da imparcialidade. Assim, o modelo do contraditório é o que se apresenta como mais apropriado para minimizar a possibilidade de quebra da imparcialidade - por conta da ausência de neutralidade daquele que gere a prova -, e foi esse o espírito da reforma de 2008. Em atenção ao contraditório o juiz julga com o que lhe for trazido pelas partes, evitando, com isso, que ele primeiro decida

19 KHALED JR. Salah Hassan. O sistema processual penal brasileiro. Civitas, Porto Alegre, v. 10, n. 2, p. 293-308, maio-ago. 2010. p. 293.

20 KHALED JR. Salah Hassan. O sistema processual penal brasileiro. Civitas, Porto Alegre, v. 10, n. 2, p. 293-308, maio-ago. 2010. p. 307. 
mentalmente - devido ao que Cordero chamou de "captura psicológica do magistrado", ${ }^{21}$ pressupondo o "primado da hipótese sobre o fato"22 - e depois busque as provas que lhe sirvam para justificar o prévio "acerto mental".

Considerando que o julgador é um ser humano e, como tal, na prática, não pode ser considerado neutro em relação àquilo que julga, Barroso refere-se à teórica neutralidade jurídica e consigna que a mesma, "pressupõe um operador jurídico isento não somente das complexidades da subjetividade pessoal, mas também das influencias sociais. Isto é: sem historia, sem memória, sem desejos. Uma ficção”. ${ }^{23}$ Assim, em razão até mesmo das peculiaridades inerentes à natureza humana não pode o juiz, salvo nas hipóteses do artigo 156 do CPP, ser o gestor direto da prova.

Admitir que o próprio juiz, que deve ser imparcial, venha a gerir diretamente a prova, levou Lopes Júnior a consignar que:

A situação é ainda mais grave quando o Ministério Público não
está na audiência e, diante da ausência do acusador, assume o
juiz esse papel, formulando as perguntas. Neste caso, mais do que
protagonista, o juiz assume uma postura substitutiva do acusador,
em flagrante incompatibilidade com o sistema acusatório, a im-
parcialidade e a própria igualdade de armas. ${ }^{24}$

Entretanto, a sinalização da jurisprudência hoje majoritária, precipuamente do STJ, autoriza o juiz a fazer o papel que deve ser reservado ao Ministério Público dentro de um sistema acusatório, ferindo, por via de consequência, o próprio texto constitucional, inclusive os princípios do contraditório e do devido processo legal, lembrando ainda, conforme consignou Giacomolli, "que o contraditório não é monopólio da defesa”. ${ }^{25}$

21 CORDERO, Franco. Guida alla procedura penale. Torino: UTET, 1986. p. 194.

BARROSO, Luís Roberto. O novo direito constitucional brasileiro: contribuições para a construção teórica e prática da jurisdição constitucional no Brasil. Belo Horizonte: Fórum, 2013. p. 106.

LOPES JÚNIOR, Aury. Direito processual penal e sua conformidade constitucional. 9. ed. rev. e atual. São Paulo: Saraiva, 2012. p. 654 e 655.

GIACOMOLLI, Nereu José. O devido processo penal: abordagem conforme a Constituição Federal e o pacto de São José da Costa Rica. 3. ed. rev., atual. e ampl. São Paulo: Atlas, 2016. p. 192. 
Os argumentos refratários à consolidação do sistema acusatório não levam em conta, ainda, que a perversidade do sistema inquisitório ao permitir que o juiz seja o gestor direto da prova e venha ele, mesmo inconscientemente, conduzir essa coleta para favorecer a hipótese mental previamente elaborada - seja ela qual for -, possa causar injustiça. E é por conta dessa questão de ordem psicológica que a mecânica adotada pela antiga redação do art. 212 - antes da reforma de 2008 - implica em reconhecer um prejuízo às partes, tanto ao acusado quanto ao Ministério Público, seja porque prejudica sua função de parte no processo, seja porque como custos legis também lhe interessa um processo justo. E esse prejuízo é também presumido pela ausência de imparcialidade judicial aliada à adoção do sistema acusatório pleno no processo penal, onde as partes é que são as gestoras diretas da prova, sendo a função do juiz pautada, em regra, pelo princípio da inércia.

Toda estrutura constitucional brasileira legitimadora do sistema acusatório demanda uma mudança de postura do CNJ, neutralizando o foco inquisitório dado por aquele colegiado ao tema em questão, aduzindo ainda Guimarães que:

Este modelo de juiz como único gestor da prova e, assim, com exclusão da efetiva participação das partes nesse processo é nocivo e conduz a decisões tortas. Ademais, praticamente reduz o contraditório e ampla defesa a tabula rasa na audiência de instrução, justamente no momento em que estes princípios seriam de fundamental importância. ${ }^{26}$

Para Giacomolli “o que estiver despido do contraditório, não é ato probatório, podendo constituir-se em ato de investigação”. ${ }^{27}$

Ademais é pertinente consignar, quanto aos poderes instrutórios do juiz, que eles continuam relacionados à atividade probatória em geral, incluindo a fiscalização do exercício da produção da prova

26 GUIMARÃES, Rodrigo Régnier Chemim. Atividade probatória complementar do juiz como ampliação da efetividade do contraditório e da ampla defesa no novo processo penal brasileiro. 2015. Tese (Doutorado em Direito) - Faculdade de Direito, Universidade Federal do Paraná, Curitiba. p. 490.

27 GIACOMOLLI, Nereu José. Reformas (?) do processo penal: considerações críticas. Rio de Janeiro: Editora Lúmen Juris, 2008. p. 22. 
diretamente pelas partes em audiência, com a possibilidade do magistrado formular questionamentos à pessoa examinada, mas, destaque-se, em caráter subsidiário. ${ }^{28}$

\section{Da Violação do deVIdo PROCESSO LEGAL}

Deve-se citar alguns exemplos, não raros, extraídos da prática forense: a) imagine-se uma audiência de instrução criminal para oitiva de testemunhas arroladas no corpo da denúncia, ausente (e aqui não se cogita das razões da ausência) o promotor de Justiça. Iniciada a audiência, o juiz passa(ria) a palavra à acusação que se encontra ausente. Sem essas perguntas passa-se a palavra à defesa e, em seguida, o magistrado faz as perguntas suplementares, ferindo o princípio do contraditório em face da ausência do autor da ação, bem como o princípio da igualdade processual; b) noutra hipótese, encontram-se ausentes promotor e advogado e o juiz conduz sozinho a audiência, produzindo prova; c) o juiz inicia a audiência e pergunta diretamente à testemunha, em seguida passando a palavra à defesa, dá por encerrada a instrução, sem sequer colher as alegações finais do Ministério Público e sentencia. Tudo isso praticado sob o argumento da inexistência de prejuízo que, aliás, como enfatizou Alexandre Morais da Rosa, "no Brasil opera o discurso do 'jeitinho', e a 'ausência de prejuízo' funciona como recurso retórico". ${ }^{29}$

As hipóteses acima referidas caracterizam error in procedendo, sem a observância dos mandamentos legais, e negam vigência à norma processual penal, de incidência obrigatória, consistindo-se em ato atípico, conforme descreve Tourinho Filho:

Quando o ato é realizado de acordo com a lei, diz-se que o ato processual é típico. Obviamente para que o ato processual possa

28 ARANTES FILHO, Marcio Geraldo Britto. O “cross-examination" como procedimento probatório para produção de prova testemunhal no direito processual penal brasileiro. 2016. Tese (Doutorado em Direito) - Faculdade de Direito, Universidade de São Paulo, São Paulo. p. 222

29 ROSA, Alexandre Morais da. Prefácio. In: PAULA, Leonardo Costa de. As Nulidades no Processo Penal. Sua compreensão por meio da afirmação do direito como controle ao poder de punir. Curitiba: Juruá Editora, 2013. p. 10. 
ser eficaz, produzindo seus efeitos jurídicos, é preciso que ele se ajuste ao modelo descrito na lei, vale dizer, é preciso seja típico. [...] Assim, há tipicidade do ato processual quando realizado em conformidade com o modelo descrito na lei. Se não houver correspondência entre o ato realizado e o paradigma legal, ele se diz atípico. ${ }^{30}$

O due process of law não contempla nenhuma das hipóteses descritas. Logo, em assim agindo, ferir-se-iam diversos princípios: da legalidade, do devido processo legal e do contraditório, não se podendo convalidar atos essencialmente nulos, cujo prejuízo é presumido, bem como estarse-ia negando vigência ao disposto no artigo 155 do CPP, que determina que o juiz formará sua convicção pela livre apreciação da prova produzida em contraditório judicial.

Permitir que o juiz (com o papel de fazer perguntas complementares, à luz do parágrafo único, do art. 212, do CPP) conduza sozinho a audiência criminal, estando ausente o Promotor, é permitir inversão e aversão tumultuária do processo, não contemplada pelo ordenamento jurídico, é negar o princípio do contraditório. A sistemática do cross-examination não deixa dúvidas: o autor da ação (Ministério Público, que também tem a inerente função de custos legis) e a defesa, portanto, agora são os primeiros a colher prova em audiência, suplementados pelo juiz. Os papéis mudaram nitidamente: a inquirição direta das testemunhas é ato - estrutural - das partes (acusação e defesa), não é mais ato do juiz suplementado por aquelas, como era no passado. O modelo presidencialista ruiu com o advento da Lei ${ }^{\circ}$ 11.690/08. Para Lopes Júnior:

Com a Reforma Processual de 2008, o art. 212 foi substancialmente alterado, não sendo mais atribuído ao juiz o papel de (inquisitorial) protagonismo na coleta da prova produzida em audiência. A mudança foi muito importante e adequada para conformar o Código de Processo Penal à estrutura acusatória desenhada na Constituição. Ao demarcar a separação das funções de acusar e julgar e, principalmente, atribuir a gestão da prova às partes, o modelo

30 TOURINHO FILHO, Fernando da Costa. Prática de processo penal. 20. ed. rev. e atual. São Paulo: Saraiva, 1998. p. 417. 
acusatório redesenha o papel do juiz no Processo Penal, não mais como juiz-ator (sistema inquisitório), mas sim de juiz-espectador. ${ }^{31}$

É claro que o juiz, além de ter a função de complementar a inquirição das testemunhas, após as partes, continua a presidir a audiência, inclusive com poder de polícia, tendo também, na lição de Mendonça, a função de fiscalizar a inquirição direta: "o magistrado exercerá importante função fiscalizatória, indeferindo as perguntas: a) que possam induzir a determinada resposta; b) que não tiverem relação com a causa; e c) que importarem repetição de outra já respondida". ${ }^{32}$

\section{DAs NUlidades No diREITO PROCESSUAL PENAL}

Sabe-se que é sobre o ato jurídico que serão operadas as nulidades. A forma da realização do ato válido está prevista em lei, o que caracteriza a tipicidade do ato jurídico processual apto a produzir efeitos dentro do processo. Se típico, o ato estará adequado à forma prevista; se violada a forma poderá ter como consequência a nulidade de tal ato. O instituto da nulidade impõe limites aos abusos porventura praticados pelo Estado e, "sob esse enfoque, o processo carrega a persona estatal, limitado pela categoria da nulidade, que será a barreira ao arbítrio". ${ }^{33}$

A nulidade é uma sanção pela prática do ato em desacordo com o modelo legal, de modo que a validade e a nulidade são qualidades do ato jurídico processual. É pertinente consignar que a nulidade relativa é passiva de sanção e pode convalidar-se, enquanto a nulidade absoluta é irreversível, não podendo o ato produzir efeito. Importante ainda registrar que nem todo ato processual penal realizado em desacordo com o modelo legal é nulo. Para isso é imprescindível saber distinguir se o

31 LOPES JÚNIOR, Aury. Ausência do Ministério Público na audiência de instrução e a postura do juiz à luz do Art. 212 do CPP. Boletim IBCCRIM, São Paulo, v. 19, n. 229, p. 3-5, dez. 2011. p. 3-5.

32 MENDONÇA, Andrey Borges de. Nova reforma do código de processo penal: comentada artigo por artigo. São Paulo: Método, 2008. p. 195.

33 PAULA, Leonardo Costa de. As Nulidades no Processo Penal. Sua compreensão por meio da afirmação do direito como controle ao poder de punir. Curitiba: Juruá Editora, 2013. p. 17. 
ato é essencial ou secundário/acessório, pois o "legislador processual penal distinguiu, no processo, os atos essenciais ou estruturais daqueles denominados acidentais ou não essenciais" ${ }^{34}$

Nessa toada, vê-se que o princípio da instrumentalidade das formas é inerente aos atos anuláveis, tipicamente não essenciais - acessórios/secundários, valendo-se ainda do pas de nullité sans grief, o que não acontece com os atos essenciais/estruturais, cujo prejuízo é presumido e a nulidade é irreversível.

Por essa concepção, Mossin preleciona que:

O princípio geral que também está encravado no art. 563 do Código de Processo Penal (pas de nullité sans grief) somente diz respeito às hipóteses configurativas das nulidades relativas, que podem ser sanadas, uma vez que, se forem elas absolutas, sua declaração se impõe sem que haja a necessidade de demonstração do prejuízo, já que este se presume. ${ }^{35}$

É pertinente, neste passo, a abordagem de algumas questões inerentes ao sistema de nulidades. O processo penal é composto por atos essenciais (ou estruturais) e atos não essenciais (ou acessórios). É sabido que quanto aos atos acessórios, ou não essenciais, se aplica o princípio pas de nullité sans grief e, não sendo comprovado prejuízo, o ato convalidar-se-á. Já quanto aos atos essenciais não se aplica tal princípio, uma vez que o prejuízo é presumido. Entretanto, tal instituto vem sendo evocado e aplicado de maneira assistemática, consignando Gloeckner que:

O princípio ne pás de nullitè sans grief acaba se tornando um dos pilares fundamentais da já denunciada casuística implementada pelos tribunais, sem falar que a sua abstração e generalidade permitem as mais mirabolantes e fantasiosas limitações aos direitos do acusado. ${ }^{36}$

34 TOURINHO FILHO, Fernando da Costa. Prática de processo penal. 20. ed. rev. e atual. São Paulo: Saraiva, 1998. p. 421.

35 MOSSIN, Heráclito Antônio. Nulidades no direito processual penal. São Paulo: Atlas, 1998. p. 63.

36 GLOECKNER, Ricardo Jacobsen. Uma nova teoria das nulidades: processo penal e instrumentalidade constitucional. Tese (Doutorado em Direito) - Faculdade de Direito da Universidade Federal do Paraná, Curitiba, 2010. p. 223. 
Conclui-se, pois, que se o ato for essencial (estrutural) presumese o prejuízo; se for acessório (não essencial), deve resultar prejuízo. Frederico Marques esclarece que:

Há, portanto, formalidades essenciais e formalidades acidentais, ou não essenciais, na estrutura do ato processual. As primeiras tornam o ato nulo, quando omissas ou violadas, independentemente de qualquer outra indagação porque o prejuízo para a acusação ou para a defesa lhes é imanente. Quanto às segundas, embora relevantes, só se tornarão causa de nulidade, se desrespeitadas ou omissas, quando a falta ou violação houver causado prejuízo às partes $(\operatorname{art.~563)})^{37}$.

O Código de Processo Penal brasileiro elenca, no artigo 564, inciso III, os atos essenciais (estruturais) que compõem o due process of law, os quais, se não observados, ensejam nulidade absoluta, cujo prejuízo, como já dito, é presumido. Também apresenta, nesse mesmo rol, os atos secundários, acessórios, estando estes elencados nas alíneas "d" (segunda parte), “e” (segunda parte), "g” e "h", a saber: d) a intervenção do Ministério Público em todos os termos da ação por ele intentada e nos da intentada pela parte ofendida, quando se tratar de crime de ação pública; e) os prazos concedidos à acusação e à defesa; g) a intimação do réu para a sessão de julgamento, pelo Tribunal do Júri, quando a lei não permitir o julgamento à revelia e h) a intimação das testemunhas arroladas no libelo e na contrariedade, nos termos estabelecidos pela lei.

Para Tourinho Filho:

O CPP, no art. 564, III, enumerou aquilo que a doutrina denomina 'atos estruturais ou essenciais do processo'. E os outros ali não elencados? São denominados 'atos acidentais ou não essenciais. Sua omissão também acarreta a nulidade? A simples omissão não, mesmo porque não se trata de ato essencial. Mas, se da sua omissão 'resultar prejuízo para a acusação ou para a defesa (CPP, art. 563) ou se da sua omissão 'houver influído na apuração da

37 MARQUES, José Frederico. Elementos de direito processual penal. 2. ed. Rio de Janeiro: Forense, 1965. v. 2. p. 415. 
verdade substancial ou na decisão da causa (CPP, art. 566), pode ocorrer a nulidade. ${ }^{38}$

E especificamente, no que tange ao Ministério Público, registra Mossin:

São atos acidentais previstos na precitada norma processual penal: a intervenção do Ministério Público em todos os termos da ação intentada pela parte ofendida, quando se tratar de crime de ação penal originalmente pública (ação penal privada subsidiária da pública) (alínea d, segunda parte). ${ }^{39}$

Numa leitura apressada, pode-se, imprecisamente, afirmar: "a intervenção do MP, nos moldes em que se encontra redigido o dispositivo, é ato acessório”. Basta uma análise sistemática do paradigma vigente para concluir que houve derrogações de alguns desses dispositivos, uma delas é a da alínea "f", do inciso III, do art. 564, com o novo modelo do júri, a saber: a obrigatoriedade de apresentação do libelo e a entrega da respectiva cópia, com o rol de testemunhas, nos processos perante o Tribunal do Júri. Sabe-se que essa exigência, com a nova roupagem do Tribunal do Júri, não existe mais. Derrogação tácita, pois. Bem como, mesmo para aqueles que assim pensavam, encontra-se parcialmente derrogada a alínea " $d$ ", (art. 564, III, d) no que tange a se entender como ato acessório a presença obrigatória do promotor de Justiça à audiência criminal na ação por ele intentada. Logo, a presença das partes em audiência, no atual modelo, assemelha-se ao disposto na alínea "l" (art. 564, III, 1), como ato estrutural: a presença da acusação e da defesa, na sessão de julgamento pelo Tribunal do Júri e, agora, repita-se, a presença também em audiência para a prática de ato essencial. Essa releitura foi imposta pela vigência da Lei n. 11.690/08.

Portanto, as hipóteses de convalidação do ato acessório, previstas nos três incisos do art. 572, do CPP, não se aplicam quando se tratar de ausência do promotor de Justiça (art. 564, III, “d”) à audiência para

38 TOURINHO FILHO, Fernando da Costa. Prática de processo penal. 20. ed. rev. e atual. São Paulo: Saraiva, 1998. p. 421.

39 MOSSIN, Heráclito Antônio. Nulidades no direito processual penal. São Paulo: Atlas, 1998. p. 44. 
inquirição das testemunhas por ele arroladas, conforme modelo vigente. Como decorrência da necessidade de se obedecer ao devido processo legal e ao contraditório, a audiência realizada sem a presença do representante do Ministério Público para colher diretamente o depoimento das testemunhas elencadas na denúncia (ato essencial), é absolutamente nula, não podendo ser esse ato convalidado, uma vez que é estrutural/ essencial, cujo prejuízo é presumido.

A doutrina esposada por Tourinho Filho expressa esse entendimento:

Para o CPP são atos essenciais ou estruturais do processo penal aqueles referidos no inciso III do art. 564. Esses atos, quando reclamados num determinado processo, não podem faltar. A sua omissão acarreta nulidade absoluta do processo. Não se indaga se houve ou não prejuízo para as partes. Presume-se o prejuízo. ${ }^{40}$

No mesmo sentido, posiciona-se Mossin, de forma esclarecedora:

A presença do Ministério Público, em todos os atos do processo por ele provocado por intermédio de regular ação ou quando a ação for intentada pelo ofendido ou seu representante legal na hipótese prevista na alínea examinada, torna-se obrigatória em face do princípio do contraditório. Por essa razão, a falta de intervenção do dominus litis em todos os termos da ação penal por ele intentada e nos da proposta pela parte ofendida, quando se tratar de crime de ação penal pública, é obrigatória, sob pena de nulidade absoluta, portanto, insanável do processo ou da relação jurídico-processual. ${ }^{41}$

\subsection{Ato PROCESSUAL PENAL E NULIDADES: BREVES CONSIDERAÇÕES}

A forma do ato processual representa uma garantia contra o arbítrio, de modo que contrariá-la mitiga o devido processo legal. Num

40 TOURINHO FILHO, Fernando da Costa. Prática de processo penal. 20. ed. rev. e atual. São Paulo: Saraiva, 1998. p. 421.

41 MOSSIN, Heráclito Antônio. Nulidades no direito processual penal. São Paulo: Atlas, 1998. p. 105. 
sistema acusatório de base constitucional não se pode relativizar a forma dos atos essenciais em busca de celeridade processual, e o que fez o CNJ foi isso: relativizou as garantias do contraditório e do devido processo legal ao permitir a realização de audiência ausente o Ministério Público. Nesse sentido Lopes Júnior destaca sua preocupação "com as absurdas relativizações diariamente feitas por tribunais e juízes, muitas vezes meros repetidores do senso comum teórico". ${ }^{42}$ E conclui que "a forma é uma garantia de que haverá condições para a efetivação do princípio constitucional”. ${ }^{43}$

E é exatamente no respeito à forma que está o cerne da questão das nulidades como efeitos do ato processual defeituoso, uma vez que a forma é de interesse público e materializa garantias constitucionais. Afirma ainda Lopes Júnior que "o ponto nevrálgico nessa matéria é que nenhum defeito pode ser considerado sanável ou insanável sem uma análise concreta e à luz da principiologia constitucional". ${ }^{44}$ Também pensamos com o autor quando afirma "que a premissa inicial é: no processo penal, forma é garantia". ${ }^{45}$

Em que pese as críticas acerca da definição de nulidades absolutas e relativas, por serem oriundas do direito civil material e, por isso, inadequadas no âmbito do processo penal, utiliza-se tal classificação como sendo, as nulidades, efeitos dos atos processuais defeituosos. Assim, as nulidades são decorrentes do defeito da forma do ato, portanto, a posteriori: se insanável o defeito - por ser o ato essencial - a nulidade será absoluta; se sanável - por ser o ato acessório - será relativa. O sistema de nulidades, pois, no processo penal, é capitaneado pelas normas constitucionais e é com esse sentido que foi empregado neste trabalho.

A inadequada compreensão desse tema, ou melhor, a manipulação ideológica dele, alimentada por uma sistemática legal retalhada, dá ensejo à captura e à deturpação de conceitos sendo "recorrente a manipulação discursiva para tratar como mera nulidade relativa àquilo que é, inequivocamente, uma nulidade absoluta". ${ }^{46}$

42 LOPES JÚNIOR, Aury. Direito processual penal e sua conformidade constitucional. 9. ed. rev. e atual. São Paulo: Saraiva, 2012. p. 1121.

43 Ibidem, p. 1128.

44 Ibidem, p. 1127.

45 Ibidem, p. 1130.

46 Ibidem, p. 1125. 
Assim, o pas de nullité sans grief funciona como se fosse o "princípio dos princípios", um megaprincípio, servindo para qualquer discurso, especialmente para relativizar toda forma - materializadora da diretriz constitucional - do ato jurídico processual.

E os reflexos dessa captura ideológica de conceito são visíveis nas decisões judiciais, sendo nítida a instabilidade gerada no sistema, "agravada pela dependência do tema às variações de humor da jurisprudência" ${ }^{47} \mathrm{O}$ desrespeito ao modelo posto, de base constitucional, referendado pelo CNJ, remete, mais uma vez, à citação de Lopes Júnior:

Não é necessário maior esforço para compreender que uma nulidade somente será absoluta se o julgador (juiz ou tribunal) quiser (...) e esse tipo de incerteza é absolutamente incompatível com o processo penal contemporâneo. ${ }^{48}$

\subsection{REFLEXOS DAS DISTORÇÕES NA JURISPRUDÊNCIA}

Conforme lembra Zaganelli ao analisar estritamente o fato do descumprimento da ordem de inquirição das testemunhas, o Superior Tribunal de Justiça diverge quanto ao efeito jurídico decorrente da violação das regras contidas no artigo 212 do Código de Processo Penal: a $5^{\mathrm{a}}$ Turma do STJ já se posicionou entendendo que a hipótese era de nulidade absoluta, enquanto a $6^{\mathrm{a}}$ Turma daquele colegiado entende que o descumprimento da regra pode causar mera nulidade relativa. ${ }^{49}$

No HC 137.089 e no HC 121.216, a $5^{\text {a }}$ Turma do STJ reconheceu a necessidade de obediência à forma processual, sob pena de ofensa ao devido processo legal, mas o fez de maneira acanhada, contemplando apenas a ordem de inquirição das testemunhas, a saber:

47 LOPES JÚNIOR, Aury. Direito processual penal e sua conformidade constitucional. 9. ed. rev. e atual. São Paulo: Saraiva, 2012. p. 1122.

48 Ibidem, p. 1129.

ZAGANELLI, Margareth Vetis. A nova regra de inquirição de testemunhas no processo penal brasileiro: uma análise interpretativa à luz da garantia constitucional do sistema acusatório. Disponível em: <https://www.diritto. it/a-nova-regra-de-inquiricao-de-testemunhas-no-processo-penal-brasileiro-uma-analise-interpretativa-a-luz-da-garantia-constitucional-do-sistemaacusatorio/>. Acesso em: 20 nov. 2017. 
A abolição do sistema presidencial, com a adoção do método acusatório, permite que a produção da prova oral seja realizada de maneira mais eficaz, diante da possibilidade do efetivo exame direto e cruzado do contexto das declarações colhidas, bem delineando as atividades de acusar, defender e julgar, razão pela qual é evidente o prejuízo quando o ato não é procedido da respectiva forma. ${ }^{50}$

Posteriormente, no HC 111.815, a $1^{\text {a }}$ Turma do Supremo Tribunal Federal se posicionou no mesmo sentido, abordando a sistemática disposta no artigo 212 do CPP, mas apenas no que tange à ordem de inquirição, "a fim de que, primeiramente, as partes interroguem as testemunhas, podendo o magistrado formular perguntas apenas quando algum esclarecimento for necessário". ${ }^{51}$

Se a desobediência à ordem de inquirição por si só enseja nulidade, com prejuízo presumido, mais razão ainda para se reconhecer a nulidade de ato processual defeituoso existe na hipótese da ausência de quem faz a inquirição direta: a parte.

Quanto ao desrespeito ao outro elemento essencial do ato, no caso a presença do Ministério Público nas audiências, a $6^{\mathrm{a}}$ Turma do STJ, no REsp 134978, entendeu que a ausência do titular da ação penal à audiência de instrução dá ensejo à nulidade relativa, cujo prejuízo deve ser demonstrado. Trata-se, à obviedade, de um equívoco construído sob o argumento de obediência aos princípios da verdade real e do impulso oficial, entretanto olvidou a desobediência ao sistema acusatório, às garantias constitucionais do devido processo legal e do contraditório, negando-lhes vigência. Lembra Marques que "a acusatoriedade celebra a audiência, a ampla argumentação e o direito à prova". ${ }^{2}$

50 BRASIL. Superior Tribunal de Justiça - STJ. HC 137089 / DF Habeas Corpus 2009/0099186-4. Relatora: Ministra Laurita Vaz. T5 - Quinta Turma. Julgado em 22/06/2010. DJe 02/08/2010.

51 BRASIL. Supremo Tribunal Federal - STF. HC 111815 / SP Habeas Corpus 9957085-85.2011.1.00.0000. Relator: Ministro Marco Aurélio. Primeira Turma. Julgado em 14/11/2017. DJ 23/11/2017.

52 MARQUES, Leonardo Augusto Marinho. Inquisitório versus acusatório: não vamos superar a dualidade sem demarcá-la. Boletim Informativo IBRASPP Ano 03, no 04, 2013/01. p. $16-18$. 
A mesma $6^{\mathrm{a}}$ Turma do STJ também assim se posicionou no HC 245.081 e no HC 230.195, onde se invocou o "princípio dos princípios" pas de nullité sans grief. Já no HC 167.284 se chegou a consignar na ementa que "não está caracterizada a nulidade decorrente da ausência do Ministério Público nas audiências de interrogatório e oitiva de testemunhas, porque sua presença não é obrigatória”. A $5^{\text {a }}$ Turma também se posicionou no mesmo sentido no HC 60.442 e no HC 47.318. E o humor oscilante da jurisprudência nesse tema nos remete ao HC 316.719 e ao AREsp $\mathrm{n}^{\circ}$ 528.020, ambos reconhecendo ser a nulidade insanável quando ausente o Ministério Público à audiência de instrução, destacando-se no AREsp 528.020 a seguinte ementa:

Deve ser mantida a decisão agravada, que reconheceu a nulidade do processo desde a audiência de instrução e julgamento, porquanto a par de realizada sem a presença do Ministério Público, do início ao fim, o Juiz de Direito substituiu o órgão acusatório ao conduzir e colher todas as provas, em atividade probatória principal e não supletiva. ${ }^{53}$

Fica, pois, evidente que "a jurisprudência brasileira nessa matéria é caótica, fruto de uma má sistemática legal" ${ }^{4}$ e que "a maioria dos julgados existentes sobre o tema convalida a produção irritual da prova". ${ }^{55}$

\section{Proposta de premissa de balizamento para interpretação DO TEMA}

O conhecimento ora produzido pretende contribuir para a percepção de que a sistemática processual penal estabelecida pela Lei 11.690/08

53 BRASIL. Superior Tribunal de Justiça - STJ. AREsp 528020 / RS. Relator: Ministro Rogério Schietti Cruz. T6 - Sexta Turma. Julgado em 15/09/2015. DJe 05/10/2015.

54 LOPES JÚNIOR, Aury. Direito processual penal e sua conformidade constitucional. 9. ed. rev. e atual. São Paulo: Saraiva, 2012. p. 1122.

55 ARANTES FILHO, Marcio Geraldo Britto. O “cross-examination" como procedimento probatório para produção de prova testemunhal no direito processual penal brasileiro. 2016. Tese (Doutorado em Direito) - Faculdade de Direito, Universidade de São Paulo, São Paulo. p. 16. 
deu nova roupagem à estrutura da realização das audiências criminais para fazer valer o disposto no art. 155, do Código de Processo Penal, a saber: o autor da ação penal tem a incumbência de produzir diretamente a prova em contraditório judicial. E isso é ato essencial, estrutural e não mero ato acessório, secundário. Na lição de Lopes Júnior "trata-se de atribuir a responsabilidade pela produção da prova às partes, como efetivamente deve ser num Processo Penal acusatório e democrático" ${ }^{56}$.

Já foi exaustivamente consignado neste artigo que ter-se-á caracterizada a nulidade absoluta quando faltar ato essencial (estrutural) do processo, conforme a teoria das nulidades, bem como diante da falta de formalidade que constitua elemento essencial do ato estrutural. Nesse sentido, a ausência do promotor de Justiça (ou procurador da República) para diretamente inquirir suas testemunhas em audiência é causa de nulidade absoluta, insanável, em face da presunção do prejuízo.

A nulidade relativa, entretanto, se caracteriza quando faltar ato acessório (não essencial) ou faltar formalidade que constitua elemento intrínseco do ato acessório e que disso tudo venha a resultar prejuízo, se aplicando, aí sim, o princípio pas de nullité sans grief. Tal circunstância, como dito no corpo deste trabalho, não se aplica à hipótese de ausência do dominus litis à audiência. Logo, insistir o juiz em realizar audiência criminal sem que esteja presente o titular da ação, sob o simplório fundamento de que havendo intimação do Ministério Público para o ato não há nulidade em vista da inexistência de prejuízo é atitude que vai de encontro à toda estrutura normativa que rege a matéria, é negar vigência ao texto de lei baseado em interpretação carente de rigidez científica. Acerca da regra do prejuízo Zaclis destaca que:

A despeito de sua importância para a construção de um modelo finalístico, referida categoria do prejuízo vem sendo aplicada de forma caótica pela jurisprudência pátria. Na realidade, o entendimento daquilo que de fato configura "prejuízo" para efeitos do artigo 563 do Código de Processo Penal se perdeu em meio a decisões controversas e confusas acerca do tema. A regra, inicialmente

56 LOPES JÚNIOR, Aury. Ausência do Ministério Público na audiência de instrução e a postura do juiz à luz do Art. 212 do CPP. Boletim IBCCRIM, São Paulo, v. 19, n. 229, p. 3-5, dez. 2011. p. 3-5. 
adotada no processo civil, foi transportada ao processo penal sem as devidas cautelas e desprovida dos necessários ajustes. ${ }^{57}$

É pertinente ainda, neste passo, registrar o que consignou Mossin quanto aos limites balizadores da aplicação do princípio pas de nullité sans grief:

De outro lado, convém deixar assente que o princípio sob consideração não deve ser instrumento do abuso e do despotismo processuais. Não se pode, dessa forma, em seu nome admitir aberrações na execução dos atos que compõem o procedimento, sob a simples alegação de que sua produção não gerou prejuízo para as partes. Logo, o princípio não autoriza a realização dos atos processuais de forma arbitrária e sem o respeito imposto pelas regras legais a eles atinentes. Em seu nome, não pode o magistrado autorizar e mesmo realizar os atos processuais sem obediência à tipicidade indicada pelo legislador, desprezando o comando normativo e o modelo legal.

Há de se admitir, de outro lado, que o preceito alinhado no art. 563 do citado diploma incide restritivamente no campo das nulidades relativas, uma vez que o prejuízo das absolutas é presumido. Logo, havendo nulidade absoluta não se deve indagar, para efeito da sanção de ineficiência, se 0 ato atípico produziu ou não prejuízo às partes. ${ }^{58}$

Estabelecidas as premissas imprescindíveis ao deslinde da questão se pode, com segurança, aduzir que o paradigma vigente até 2008 ruiu e o paradigma atual (advindo da Lei 11.690/08) estabelece o balizamento da matéria, assumindo as partes (acusação e defesa) o papel primordial de produzirem suas provas, não podendo tal direito ser suprimido por magistrado que queira produtividade à revelia das normas cogentes que regem a matéria, o que Bohm chamou de fast-food jurisdicional ou, a "McDonaldização" da

57 ZACLIS, Daniel. A regra do prejuízo e as nulidades processuais: construção de um modelo racional de aplicação do `pas de nullité sans grief' no âmbito do processo penal brasileiro. Dissertação (Mestrado em Direito) - Faculdade de Direito da Universidade de São Paulo, São Paulo, 2015. p. 4.

MOSSIN, Heráclito Antônio. Nulidades no direito processual penal. São Paulo: Atlas, 1998. p. 62/63. 
justiça criminal. ${ }^{59} \mathrm{O}$ modelo paradigmático descrito neste trabalho funciona como premissa fundamental na interpretação coerente do tema.

Logo, em sendo essencial a presença do Ministério Público em audiência, pois se trata da prática de ato estrutural conforme modelo estabelecido pelo novo paradigma acima exposto, o efeito decorrente dessa configuração normativa é que sua ausência ao ato resulta nulidade absoluta, não se aplicando o brocardo pas de nullité sans grief, tendo em vista ser o prejuízo presumido.

É contraproducente insistir em realizar audiência criminal para oitiva de testemunhas arroladas na denúncia sem a presença do Ministério Público, pois isso desrespeita o devido processo legal, fere o contraditório e nega vigência ao modelo posto, haja vista "que o 'cross-examination' é ontologicamente presencial". ${ }^{60}$

Registre-se, outrossim, que o argumento de que a intimação do Ministério Público por si só basta é um sofisma que, apesar de razoavelmente construído, parte de premissa equivocada, consistente no olhar para o modelo anterior a 2008, não mais existente. A mera intimação não substitui o ato essencial necessário à validade do processo - inquirição direta das testemunhas - e, ademais, é secundária e sem força para elidir o modelo vigente. Neste momento histórico, com o modelo posto, assim como acontece no Tribunal do Júri, a ausência do representante do Ministério Público, mesmo intimado, impõe o adiamento do ato, sob pena de nulidade absoluta.

O mesmo não acontece, porém, quando atua o MP na qualidade de custos legis, intimado para atos não essenciais, neste caso se aplicando ainda o disposto residual do art. 564, III, “d”, segunda parte, do CPP. São duas posições processuais absolutamente distintas e que não podem ser confundidas, como vem acontecendo na prática: como custos legis a mera intimação produz efeitos válidos e não macula o ato a ser praticado;

59 Sobre isso, ver: BOHM, Robert M. "McJustice": On the McDonaldization of criminal justice. Justice Quarterly, v. 23, n. 1, p. 127-146, 2006.

60 ARANTES FILHO, Marcio Geraldo Britto. O “cross-examination" como procedimento probatório para produção de prova testemunhal no direito processual penal brasileiro. 2016. Tese (Doutorado em Direito - Faculdade de Direito, Universidade de São Paulo, São Paulo. p. 85. 
como titular da ação a presença ao ato é essencial, sobretudo à audiência. Mossin destaca que:

De outro lado, se o ato processual realizar-se sem que o Ministério Público seja intimado, ou, sendo-o, não compareça, quer justificando quer não sua ausência, há de se distinguir ambas as situações catalogadas na alínea examinada: se a ação for pública plena ou condicionada (art. 24, CPP), a nulidade será insanável; se a ação penal for privada subsidiária da pública (art. 29, CPP), a nulidade será relativa, e sua ocorrência dependerá de ter havido comprovadamente prejuízo ao litisconsorte ativo obrigatório, por ser ela sanável nos termos do art. 572 do Código de Processo Penal. ${ }^{61}$

Se não bastassem todos esses argumentos, traz-se à lume ainda os seguintes aspectos: no processo civil, a ausência do autor dá ensejo à contumácia em face da demanda ser disponível, podendo a ação ser extinta sem julgamento do mérito, onde a ausência do custos legis, intimado, não causa nulidades. Se a ação cível (privada) não pode prosseguir sem o autor, os atos não podem ser realizados estando ausente o autor, qual a razão para que no processo penal isso possa acontecer? Nenhuma, pois no processo penal há a indisponibilidade da ação e a ausência do autor titular dela - não enseja contumácia. Logo, a ação não pode ser extinta e o ato também não pode ser realizado ausente o autor, pois o juiz não pode substituir a parte autora. Ademais, como já dito, o juiz tem papel bem definido no modelo vigente, fazendo perguntas complementares e, se o autor estiver ausente e, obviamente, não tiver feito perguntas, o magistrado não pode complementar o que não existiu. Se assim agir, haverá nulidade absoluta por ferir o contraditório e o devido processo legal.

Tratar como se fosse relativa a nulidade absoluta é um grave equívoco. Como registra Paschoal "pode-se afirmar, assim, que modernamente, as nulidades absolutas acabaram se tornando relativizadas, sendo, assim, menos absolutas, mais relativas". ${ }^{62}$

${ }^{61}$ MOSSIN, Heráclito Antônio. Nulidades no direito processual penal. São Paulo: Atlas, 1998. p. 106.

62 PASCHOAL, Jorge Coutinho. O prejuízo na teoria das nulidades processuais penais e sua análise jurisprudencial nos tribunais superiores. Dissertação (Mestrado em 2014) - Faculdade de Direito da Universidade de São Paulo, São Paulo, 2014. p. 23. 


\section{Considerações Finais}

Os atos essenciais/estruturais não podem ser realizados sem seu autor: a denúncia cabe ao MP; as decisões ao Juiz; a inquirição das testemunhas às partes, podendo o juiz complementá-las. Ausente a acusação e a defesa na sessão de julgamento pelo Tribunal do Júri (art. 564 , III, 1), o ato será adiado. No mesmo sentido, sob o paradigma instituído pela Lei $\mathrm{n}^{0} 11.690 / 08$, ausentes as partes à audiência criminal, $o$ ato deve ser adiado, eis que se trata de ato estrutural, essencial. Trabalhando com outros fundamentos, Gonzalez também chega à mesma conclusão: "Destarte, se o Ministério Público não comparece na audiência de instrução criminal, pouco importando se devidamente intimado ou não para aquele ato, o juiz deverá designar nova audiência, sob pena de nulidade absoluta". ${ }^{63}$

O modelo paradigmático descrito neste trabalho funciona como premissa fundamental na interpretação coerente do tema e se espera que sirva de balizamento às decisões judiciais vindouras acerca do assunto, bem como ao conhecimento científico a ser produzido na área processual penal a partir do reconhecimento da nulidade absoluta pela não intervenção do representante do Ministério Público em atos essenciais da ação penal pública.

\section{REFERÊNCIAS}

AMARAL, Augusto Jobim do. Nas entranhas do processo penal: para uma viragem democrática. Revista da Faculdade de Direito da UERJ, v. 2, n. 26, 2014. https:// doi.org/10.12957/rfd.2014.4751

ARANTES FILHO, Marcio Geraldo Britto. O “cross-examination" como procedimento probatório para produção de prova testemunhal no direito processual penal brasileiro. 2016. Tese (Doutorado em Direito) - Faculdade de Direito, Universidade de São Paulo, São Paulo.

${ }^{63}$ GONZALEZ, André. A nulidade absoluta da audiência de instrução criminal realizada sem a presença do Ministério Público. São Paulo: All Print, 2009. p. 71. 
BARROSO, Luís Roberto. O novo direito constitucional brasileiro: contribuições para a construção teórica e prática da jurisdição constitucional no Brasil. Belo Horizonte: Fórum, 2013.

BOHM, Robert M. "McJustice": On the McDonaldization of criminal justice. Justice Quarterly, v. 23, n. 1, p. 127 - 146, 2006. https://doi. org/10.1080/07418820600552576

CORDERO, Franco. Guida alla procedura penale. Torino: UTET, 1986.

GIACOMOLLI, Nereu José. O devido processo penal: abordagem conforme a Constituição Federal e o pacto de São José da Costa Rica. 3. ed. rev., atual. e ampl. São Paulo: Atlas, 2016.

GIACOMOLLI, Nereu José. Reformas (?) do processo penal: considerações críticas. Rio de Janeiro: Editora Lúmen Juris, 2008.

GLOECKNER, Ricardo Jacobsen. Nulidades no processo penal. - 3. ed. - São Paulo: Saraiva, 2017.

GLOECKNER, Ricardo Jacobsen. Uma nova teoria das nulidades: processo penal e instrumentalidade constitucional. Tese (Doutorado em Direito) - Faculdade de Direito da Universidade Federal do Paraná, Curitiba, 2010.

GONZALEZ, André. A nulidade absoluta da audiência de instrução criminal realizada sem a presença do Ministério Público. São Paulo: All Print, 2009.

GUIMARÃES, Rodrigo Régnier Chemim. Atividade probatória complementar do juiz como ampliação da efetividade do contraditório e da ampla defesa no novo processo penal brasileiro. 2015. Tese (Doutorado em Direito) - Faculdade de Direito, Universidade Federal do Paraná, Curitiba.

KHALED JR. Salah Hassan. O sistema processual penal brasileiro. Civitas, Porto Alegre, v. 10, n. 2, p. 293-308, maio-ago. 2010.

LIMA, Charles Hamilton Santos; CARNEIRO, André Silvani da Silva. A função do Ministério Público é essencial, não apenas eventual. Disponível em: <http://www. conjur.com.br/2017-jul-17/mp-debate-funcao-ministerio-publico-essencial-nao-apenas-eventual>. Acesso em: 01 ago. 2017.

LOPES JÚNIOR, Aury. Ausência do Ministério Público na audiência de instrução e a postura do juiz à luz do Art. 212 do CPP. Boletim IBCCRIM, São Paulo, v. 19, n. 229, p. 3-5, dez. 2011.

LOPES JÚNIOR, Aury. Direito processual penal e sua conformidade constitucional. 9. ed. rev. e atual. São Paulo: Saraiva, 2012. 
MARQUES, José Frederico. Elementos de direito processual penal. 2. ed. Rio de Janeiro: Forense, 1965. v. 2.

MARQUES, Leonardo Augusto Marinho. Inquisitório versus acusatório: não vamos superar a dualidade sem demarcá-la. Boletim Informativo IBRASPP - Ano 03, $\mathrm{n}^{\mathrm{o}}$ 04, p. 16-18, 2013/01.

MENDONÇA, Andrey Borges de. Nova reforma do código de processo penal: comentada artigo por artigo. São Paulo: Método, 2008.

MOSSIN, Heráclito Antônio. Nulidades no direito processual penal. São Paulo: Atlas, 1998.

NUCCI, Guilherme de Souza. Código de Processo Penal comentado. 15. ed. rev., atual. e ampl. Rio de Janeiro: Forense, 2016.

PACELLI, Eugênio. Curso de processo penal. 21. ed. rev., atual. e ampl. São Paulo: Atlas, 2017.

PASCHOAL, Jorge Coutinho. O prejuízo na teoria das nulidades processuais penais e sua análise jurisprudencial nos tribunais superiores. Dissertação (Mestrado em Direito) - Faculdade de Direito da Universidade de São Paulo, São Paulo, 2014. https://doi.org/10.11606/d.2.2016.tde-08082016-143245

PAULA, Leonardo Costa de. As Nulidades no Processo Penal. Sua compreensão por meio da afirmação do direito como controle ao poder de punir. Curitiba: Juruá Editora, 2013.

TOURINHO FILHO, Fernando da Costa. Código de processo penal comentado. São Paulo: Saraiva, 1997. v. 2.

TOURINHO FILHO, Fernando da Costa. Prática de processo penal. 20. ed. rev. e atual. São Paulo: Saraiva, 1998.

ZACLIS, Daniel. A regra do prejuízo e as nulidades processuais: construção de um modelo racional de aplicação do 'pas de nullité sans grief' no âmbito do processo penal brasileiro. Dissertação (Mestrado em Direito) - Faculdade de Direito da Universidade de São Paulo, São Paulo, 2015. https://doi.org/10.11606/d.2.2015. tde-09112015-143036

ZAGANELLI, Margareth Vetis. A nova regra de inquirição de testemunhas no processo penal brasileiro: uma análise interpretativa à luz da garantia constitucional do sistema acusatório. Disponível em: <https://www.diritto.it/a-nova-regra-de-inquiricao-de-testemunhas-no-processo-penal-brasileiro-uma-analise-interpretativa-aluz-da-garantia-constitucional-do-sistema-acusatorio/>. Acesso em: 20 nov. 2017. 


\section{Informações adicionais e declarações dos autores (integridade científica)}

Agradecimentos (acknowledgement): Agradeço ao editor Vinicius Vasconcellos pelas referências bibliográficas sugeridas, bem como a Márcio Arantes Filho por disponibilizar cópia do texto final de sua tese, antes mesmo da publicação, que assim contribuíram ao aprimoramento deste artigo.

Declaração de conflito de interesses (conflict of interest declaration): o autor confirma que não há conflitos de interesse na realização das pesquisas expostas e na redação deste artigo.

Declaração de coautoria e especificação das contribuições (declaration of authorship): todas e somente as pessoas que atendem os requisitos de autoria deste artigo estão listadas como autores; o autor se responsabiliza integralmente por este trabalho em sua totalidade.

Declaração de ineditismo e originalidade (declaration of originality): o autor assegura que o texto aqui publicado não foi divulgado anteriormente em outro meio e que futura republicação somente se realizará com a indicação expressa da referência desta publicação original; também atesta que não há plágio de terceiros ou autoplágio. 
Dados do processo editorial

(http://www.ibraspp.com.br/revista/index.php/RBDPP/about/editorialPolicies)

- Recebido em: 27/08/2017

Equipe editorial envolvida

- Controle preliminar e verificação de plágio: 02/09/2017

- Ressubmissão: 14/09/2017

- Editor-chefe: 1 (VGV)

- Revisores: 4

- Controle preliminar e verificação de plágio: 17/09/2017

- Avaliação 1: 30/10/2017

- Avaliação 2: 06/11/2017

- Avaliação 3: 08/11/2017

- Avaliação 4: 08/11/2017

- Decisão editorial preliminar: 11/11/2017

- Retorno rodada de correções: 03/12/2017

- Decisão editorial 2: 20/12/2017

- Retorno rodada de correções 2: 21/12/2017

- Decisão editorial final: $21 / 12 / 2017$

\section{COMO CITAR ESTE ARTIGO:}

CARVALHO, Francisco Ortêncio de. A nulidade absoluta pela não intervenção do representante do Ministério Público em atos essenciais da ação penal pública. Revista Brasileira de Direito Processual Penal, Porto Alegre, vol. 4, n. 1, p. 337-368, jan./abr. 2018. https://doi.org/10.22197/rbdpp.v4i1.107

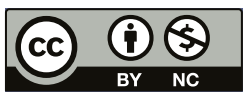

Esta obra está licenciada com uma Licença Creative Commons Atribuição-NãoComercial 4.0 Internacional. 